\title{
低温サウナ室内の伝熱と熱流動
}

\section{Heat transfer in a low temperature sauna}

\author{
○学 松本 欣和(日本工大) 正 原 利次(日本工大) 佐藤 貴浩(日本工大・学)
}

Yoshikazu MATSUMOTO, Toshitsugu HARA, Takahiho SATO

Dept. of Systems Engineering, Nippon Institute of Technology, Gakuenndai, Miyasiro, Saitama

\begin{abstract}
Experimental and calculated investig ation on heat transfer in a low temperature sauna was made. Low temperature.sauna was usually heated up by a radiation panel heater at the ceiling to 50 degree $C$. In order to examine how heat transfers from the radiation heater to a human body in a saun a room, temperature and velocity distribution air were examined by the experiment and calculation of indoor air flow. It was found that heat flowed from the radiation heater to the human body mainly through air convection and wall radiation, not direct radiation from the heater.
\end{abstract}

Key Words: heat transfer, radiation, sauna, human body, sonic wave

1.はじめに

遠赤外線は、食品加熱や健康医療器具などの分野で利用 され、我々の生活に深く浸透してきているが、生体への影 響についてはまだ解明されていない部分が多く、今後さら に明らかにすることが必要である。

本研究は、遠赤外線放射パネルで加熱するいわゆる低温 サウナ室内で，本当に低温の直接放射で人体が充分に加熱 されるのか，を明らかにするために行ったもので，サウナ 室内での熱流動を実験と熱流動シミュレーションで検討し， さらに人体各部の温度変化を測定して，より効果的な利用 方法を検討したものである。

\section{2. 実験装置と方法}

図 1 のような緃、横各 $1.8 \mathrm{~m}$ 、高さ $2.2 \mathrm{~m}$ のサウナ室を作 り、壁には厚さ $15 \mathrm{~mm}$ の断熱材（発泡スチロール)を使用し た。加熱装置として，床面から $2.0 \mathrm{~m}$ の位置に $0.8 \mathrm{~m} \times 0.9$ $\mathrm{m}$ の遠赤外線放射パネル (入力 $200 \mathrm{~V}, \max 14 \mathrm{~A}$, 温度制御器 付）を下向きに設置した。サウナ室周囲の空気温度は $20^{\circ} \mathrm{C}$ であった。

サウナ室内の温度分布の测定のため、素線径 $0.3 \mathrm{~mm} の \mathrm{CC}$ 熱電対を鉛直方向 4 箇所，水平方向 3 䈏所の計 12 個所と， 貫流ファン吹出し口に計 5 籄所と, 計 19 箇所で測定した。 また、壁かららの熱漏洩の計算のためザウナ室断熱壁の内外 の表面温度を測定した。人体への暖房効果を調べるために、 被験者の上半身裸体の表面温度を, 入室前と入室後 10 分ま で 2 分毎，サーモカメラを用いて測定した。

\section{3. 実験結果と検討}

熱電対で測定したサウナ室内の各部の温度変化を図 2 に 示す。放射パネル温度の変化でわかるように，制御方法が 加熱後断続運転になるため, 放射パネル表面の温度はスイ

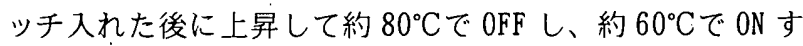
るように 0N-0FF を繰り返して大きく変化している.しかし 室内中央（床から $1.0 \mathrm{~m}$ ) での空気温度は $50^{\circ} \mathrm{C}$ 前後で比較 的安定し、壁（中央）内側の表面温度も室内空気温度と同 じように変化している。また、壁（中央）外側の表面温度

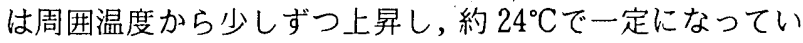
る。

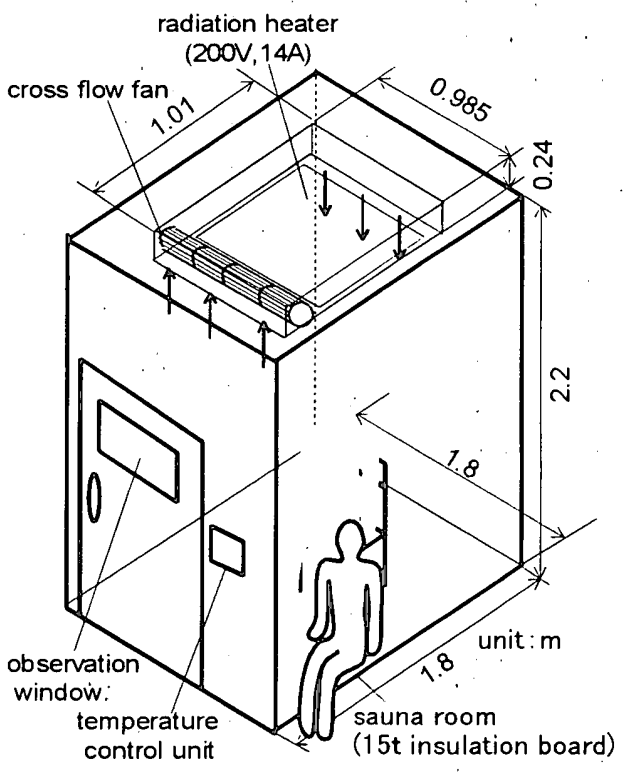

Fig. 1 Experimental apparatus

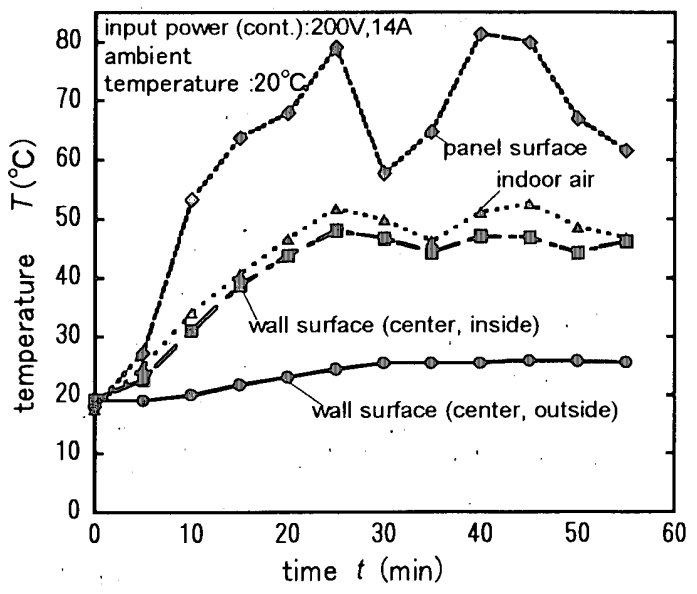

Fig.2 Temperature change 
図 3 は市販の熱流動解析ソフト(PHOENICS)により, 実測 の吹出し風速と空気温度を用いてサウナ室内の流動状況を シミュレーションしたものである. 吹出しロでの下向き流 速が大きいため空気が床面まで到達していることがかかる. これと比較するためにサウナ室中央断面での鉛直方向の速 度分布と温度分布を測定した。結果を図 4 に示す。

図 4 は室内中央での風速と温度の実験值と計算值を示し ている。両者の值はやや異なっているが,傾向は似ており， 空気温度は実験值と計算值とも吹出し口直後で高く、下降 にしたがって低下している.また風速は上部では両者は異 なっているが、床面付近では両者とも $4 \mathrm{~m} / \mathrm{s}$ 前後の強い風が 吹いている。以上から、熱量の大部分は空気による対流伝 熱の可能性が考えられた。

図 5 に，実験により得られた温度分布と放射伝熱"の計 算により求めた, 低温サウナ室での熱の流れの結果を示す. 入室 10 分後を例に示したが, 遠赤外線サウナとはいえ放射 パネルから直接人体に放射される熱量は $10 \%$ 前後と小さく， 熱のパネル熱の殆どは空気を介して壁に，一部は人体に入 る．壁に入った熱は再度放射により人体に入り，この量は パネルから直接入る量に匹敵する。この熱系統を知ること により効果的にサウナを利用することが考えられる.

図 6 にサウナ室内の人体の表面温度分布を示す。図中(a) はサウナ室内で立居でいた場合で, 顔や屃は温度が上がっ ているが腹部は温度が上がっていない。もともと熱容量の 大きな腹部は温まり難いようである.図 6(b)は改善後の 横座したときの温度分布を示す。図6 (a) と比較すると、他 の部分はあまり変化がないが、腹部の温度が約 $2^{\circ} \mathrm{C}\left(35.0^{\circ} \mathrm{C}\right.$ $\left.\rightarrow 37.0^{\circ} \mathrm{C}\right)$ 上昇し、胸部の温度と同等になっていることが わかる。被験者へのアンケートによると感覚的にも充分暖 かくなったという評価を得た。遠赤外線加熱といっても主 な熱担体である温風を直接腹部にあてることにより暖房効 果を改善することが出来る。

\section{4.まとめ}

遠赤外線を加熱隇とする低温サウナの熱流動を実験と熱 流動シミュレーションで検討し，遠赤外線の放射熱だけで は人体は温まり難く、吹出し温風を直接人体にあてること により、暖房効果を改善することが出来た。

最後に、実験装置の製作に際し放射パネルを提供して頂 いたミサト侏に感謝いたします。

\section{5. 参考文献}

1）伝熱ハンドブックーソフト付き-，機械学会 （1993）

2）川口, 遠赤外放射のサウナへの応用、電熱社 (1986) p. $52-56$.

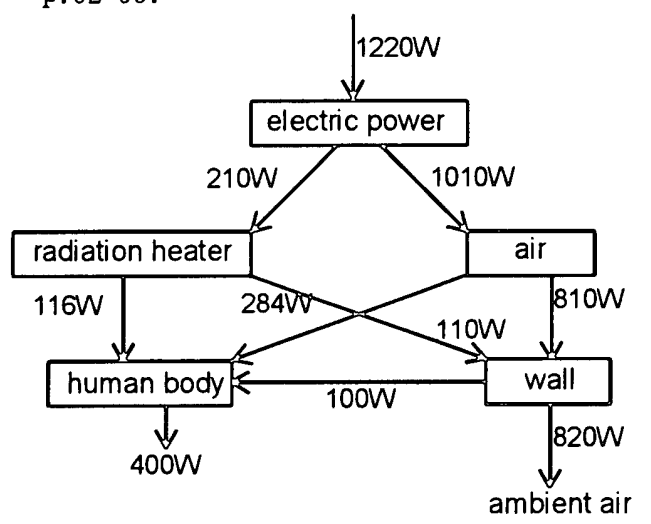

Fig. 5 Heat Transfer in a sauna room (after $10 \mathrm{~min}$.)

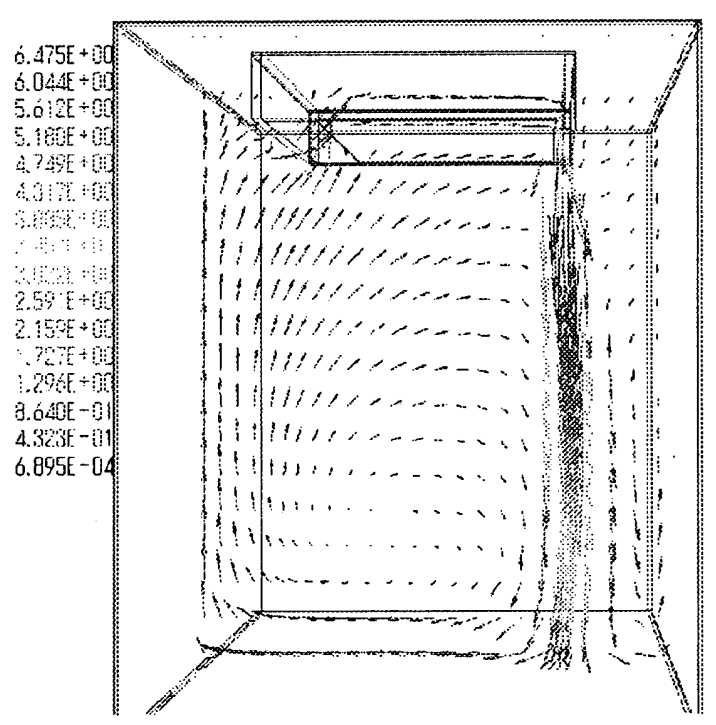

Fig. 3 Velocity distribution

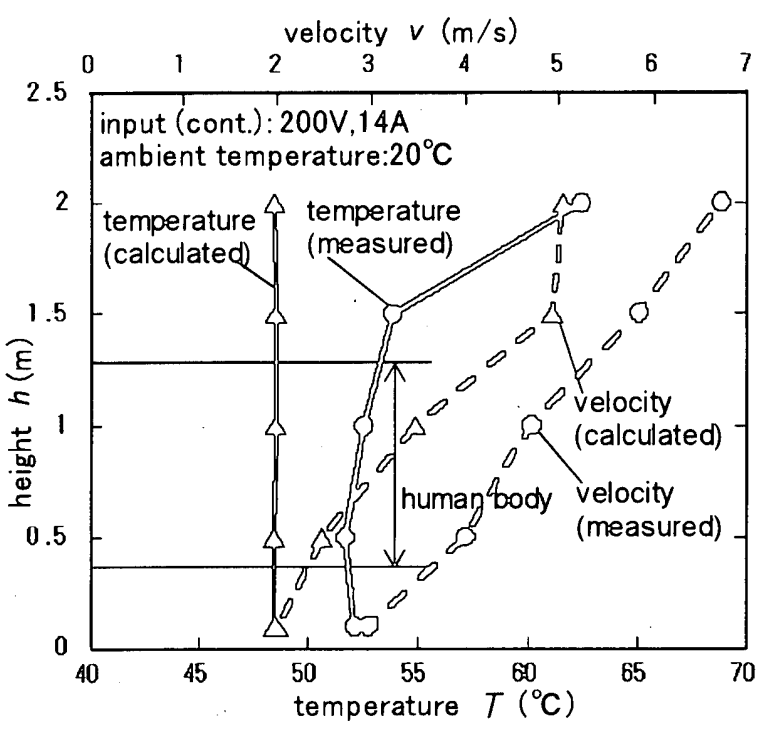

Fig. 4 Temperature and velocity distribution (Calculated and measu red)

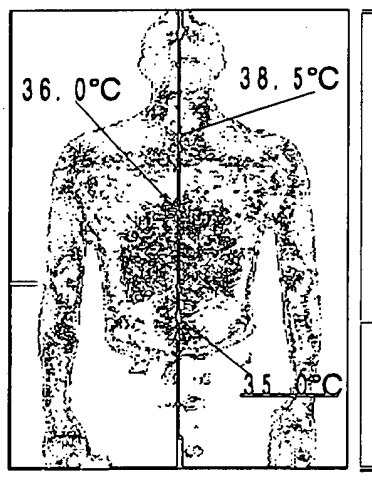

(a) standing

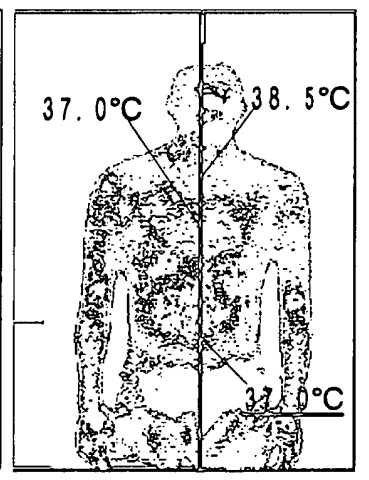

(b) lying
Fig. 6 Comparison of skin temperature (after 10 minutes) 